\title{
A NEW APPROACH IN WORKSPACES ANALYSIS FOR ROTARY ENGINES CASE
}

\author{
Chioreanu, N. \& Catas, A.
}

Abstract: Within this paper the authors provide new aspects concerning operating principles of a certain rotary piston heat engines, namely Wankel engine and Panu-Stanescu engine, the last one is a Romanian letters-patent of engineers Mihai Panu and Gheorghe Stanescu. Taking in consideration the work spaces with variable volume which are created during the engine running, the authors develop a theoretical approach of the determination of the volume function variation in the Wankel rotary engine case. The paper presents the parameter equations of the inner surface sections of the carcasses of the piston section and the determination of the volume function variation of one chamber, in each case. Due to this fact one can obtains an optimization of the operational factors in the case of the above mentioned rotary piston heat engines.

Key words: rotary engine, hypocycloid, Green's formula
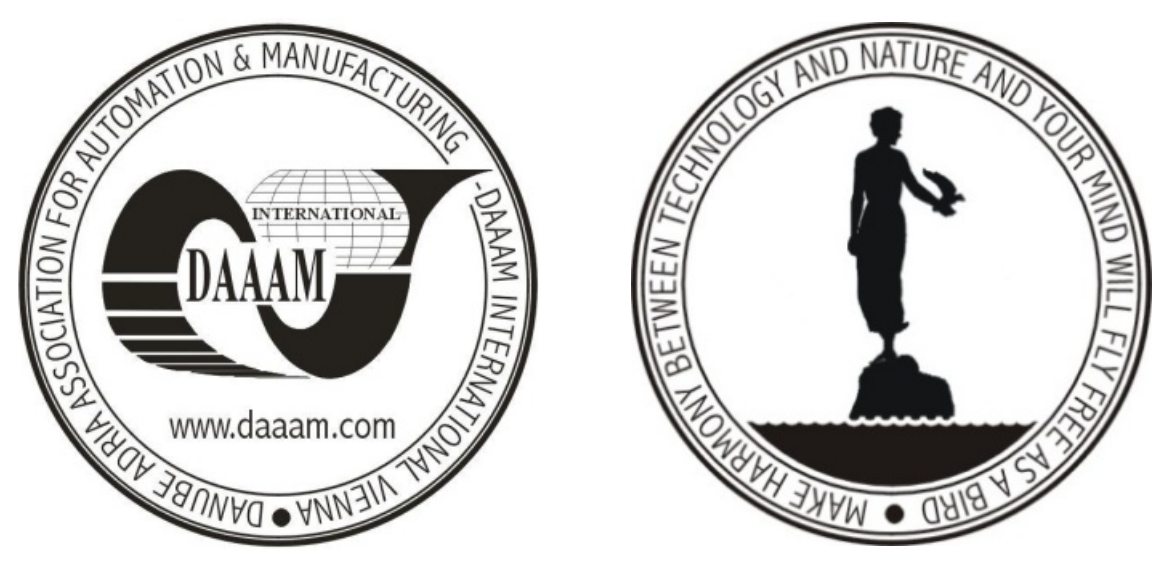

Authors' data: Dr.Chioreanu, N[icolae $]^{*}$; Dr. Catas, A[driana $]^{* *}$, ${ }^{*}$ University of Oradea, Faculty of Environmental Protection, Gen. Magheru 26, Oradea, Romania, **University of Oradea, Department of Mathematics, 1 University Street, 410087, Oradea, Romania, nchioreanu@uoradea.ro, acatas@gmail.com

This Publication has to be referred as: Chioreanu, N[icolae] \& Catas, A[driana] (2009). A New Approach in Workspaces Analysis for Rotary Engine Case, Chapter 28 in DAAAM International Scientific Book 2009, pp. 261-272, B. Katalinic (Ed.), Published by DAAAM International, ISBN 978-3-901509-69-8, ISSN 1726-9687, Vienna, Austria

DOI: $10.2507 /$ daaam.scibook.2009.28 